\title{
Assessing the Perception of Academicians about Organizational and Personal Aspects of Job Stress and Performance: A Qualitative Study
}

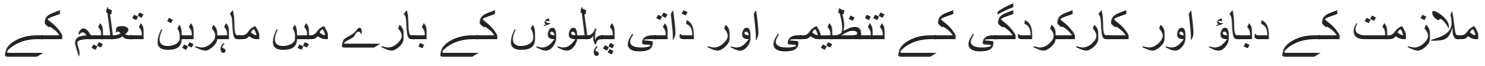

$$
\begin{aligned}
& \text { تاثز ات كا اندازه للخانا: ايك خوبى مطالعه }
\end{aligned}
$$

https://orcid.org/0000-0003-1820-9155

Muhmmad Furqan Ashraf ${ }^{13}$

https://orcid.org/0000-0003-0719-0479

\begin{abstract}
Performance of academicians negatively associated with job stress and many other factors most obvious are institutional and personal characteristics of academia. Academia performs assigned tasks within their position and expected roles at universities. Qualitative research study was conducted to assess the perception of academicians about organizational and personal aspects. A purposive sample of 60 participants as academia heads and academia (teachers) from eight public sector universities were targeted. Semi-structured face to face and telephonic interviews were conducted by using interview guide/checklist with open statements for getting different perception and working experience of academia heads as (Deans, Department Heads, InCharge), and of academia (teachers). Data were recorded in the form of mobile recorder and written notes. Transcripts were written and thematic analysis was used to analyze the data for important themes relevant to research objectives. Results of research shows that academia heads assign different tasks to academia, sometime oppose the interest of academia, may create stressful situation. Academia heads have diverse responsibilities to take part in different activities to obtain institutional goals, based on their domain, also face some stress. It was suggested that academia heads must assign work according
\end{abstract}

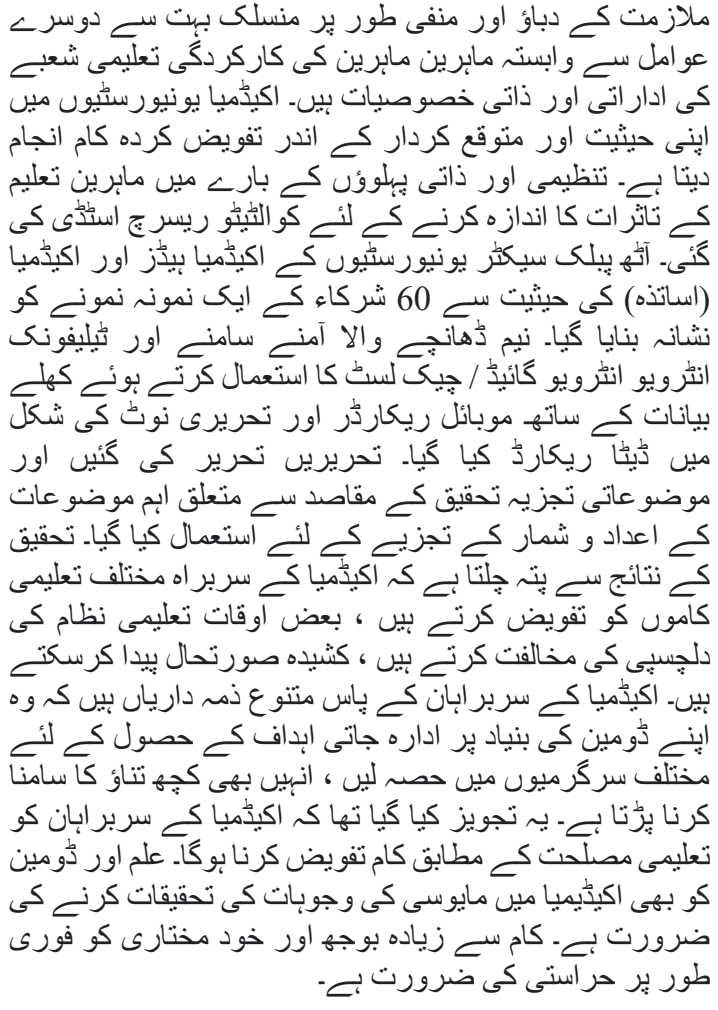

\footnotetext{
${ }^{13}$ Department of Sociology, Government College University, Faisalabad, Punjab, Pakistan.
} 
to academia interest; knowledge and domain, also need to take investigate reasons of disappointment among academia. Work overload and autonomy need urgent concentration.

Keywords: Perception, Academicians, Organizational and Personal Aspects, Job Stress, Performance, Qualitative Study

\section{Introduction}

Working performance of academia is related with many institutional factors and personal characteristics of academic staff. Universities are educational hub, through technological advancement it provides learning platform for academia. Meeting increasing demand of technological change, universities are working in Punjab under control of Higher Education Commission that consists of degree awarding institutions DAI's (Worl Bank, 2007). Institutions demand more intensive work from their academia in research, teaching and administration, create stress among academia regarding research productivity as well (Ghabban et al. 2019). The influential working conditions and organizational culture can enhance and reduce satisfaction level of academia (Masum, Azad, \& Beh, 2015).

Stress is feeling of physical tension which occurs for required demand of workplace that ought to be dependable on individuals but often exceed on his ability and interest (Hellriegel \& John, 2004). Job stress is defined as external harmful factors at work place create bad environment, for issue may be social, psychological and physical in nature (Greenberg and Baron, 2007). Others are defined stress as individuals reactions toward working environment that is seem to be emotionally and morally threatening, perceived by different individuals (Ivancevich and Matteson, 2002; Jamal, 2005), degree of stress negatively affect the performance of academia (Zafar et al., 2015), as Prerna and Agarwal, (2015) states that job stress consist of different level, sometime medium, low or high affect the job performance, affected by work over load, role conflict and work ambiguity.

\section{Significance of study}

University academia is under stress due to performing different challengeable tasks at universities. This study provides a platform to describe their experiences about stress and performance. Many of academia staff socially, physically and psychosocially hilted by routine work, their stress level increase and life work balance is not committed. Universities are

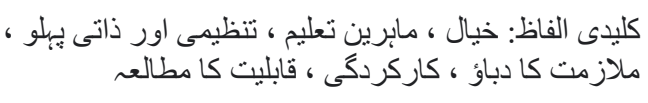

responsible to provide nation a social, cultural and economical foundation, unfortunately, overburden and institutional demand due to increasing knowledge economy around the world, require more extensive work. This study suggests important implications for policy makers, draw important policies to overcome stress level of academia to performing better for excellent personal and institutional growth.

\section{Research Gap}

Many academic studies have been conducted on stress and students performance, through assessing the grades and achievement. Therefore, academia heads and teachers are backbone of any academic institution. To meet the increasing demand of quality education, academia come to face more stressful situation that is need to be addressed through their own perception and experience. This study will fill out this gap, and suggest some important suggestions to reduce the level of stress for better working performance. Limited studies are available on this topic related to academia heads and teacher perception about job stress and working performance.

\section{Main Objective}

- To understand perception and knowledge about different Organizational and personal aspects of job stress and working performance.

\section{Literature Reviewed}

\section{Organizational and personal aspects}

Academia performance is related with various personal and organizational factors. As job satisfaction, training, and relations at work may contribute its effect negatively on job performance. Khan, Yousf \& Azam, 2014 conducted a conceptual review and stated that teachers at universities are under stress, the issue should be resolve at individual and organizational level. 


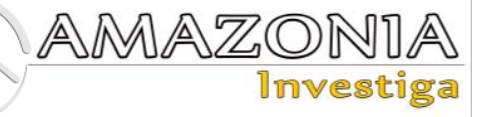

Autonomy of Work

Autonomy of job is a degree which provides considerable freedom to the individual and shaping the process in the direction of carrying out job. Some important features are task identity and significance and others views of job, leads to the responsibility of work performance such as high work performance is due because of motivation Hackman and Oldham (1975), it becomes crucial aspect to increase intrinsic motivation of employees (Morrison et al. 2005), give independence to employee for performing their functional tasks because of maintain responsibility keeping on, leads to more effective outcome (Gellatly \& Gregory, 2001)

\section{Work overload and Decision making}

Working employees wellbeing is connected with job satisfaction, organizational commitment on the behalf of work autonomy promote decision making, therefore, work overload distress the behaviour. A study conducted by (Gashi, 2014) and concluded that negative effect of work overload on job autonomy, satisfaction and decision making prelude performance, it further leads to low academic productivity due to physical health condition as fatigue add more physical and metal issues influencing on efficiency and health (Fan \& Smith, 2017).

\section{Functional communication model}

Communication based upon direct or indirect connection among academicians working in same institution, productive information, knowledgeable resources can be shared and discussion for functional tasks. Proper channel of communication is effective for academic production (Badau, 2018) in linkingas Toohey (1995) noted that purposeful communications at workplace may be impacted by bad behavior and assessed as a secured and agreeable approach to move inconvenience. These issues ought to achieve being talked that by what implies one might be ensured and protected at workplace. Moreover common behavior and action to keep up phenomenal need of the individual's prosperity at workplace.

\section{Stress-coping strains model}

Osipow and Spokane indicated stress coping strain that is critical segment joins a ton of solidarity of the past models. This model underlined on three disconnects anyway related zones for instance work pressure, work stress and adjusting resources open to contradict the effects of work pressure. Workers in any occupations may include an assortment of social positions, which may cause pressure (Osipow and Spokane,1983).

\section{Research Methodology}

The research study "Perception of academicians about organizational and personal aspects of job stress" was equipped by using qualitative approach. A sample of 60 academicians was targeted by using purposive sampling technique from eight universities of Punjab including academia heads (Dean, Chairperson, Incharge) and academia (Teacher). According to Etikan, Musa, and Alkassim (2016) purposive sampling is a deliberate choice of participants who possess some monogamous qualities for required information, their willingness and relevant experience also necessary, it is non random technique that does not need certain theories or set number of respondents. Semi structured face to face and telephonic interviews were conducted, due to prevailing situation of Covid19 , telephonic interviews are considered suitable method of data collection, prior studies has suggested us to conduct telephonic interviews as (Holstein \& Gubrium, 2003) argued that qualitative interviews are conducted that provide empirical data about social word by asking people about their life experiences, telephonic conversation is short and comprehensive in particular context (Irvine, 2011) and its suitability may have some pros and cons but ultimately different empirical researches are available where telephonic interviews are used in field of social science and management (Farooq \& Villiers, 2017; Stephens, 2007). Data was recorded through mobile recorder and in form of written notes. These notes and recording listen very carefully with the help of researcher who helped in making transcription of the data. Transcription is a process of witting up collected data into meaningful, clear and readable form, free from errors, pauses and distortions, for further understanding what meaning the data is describing. Transcribed data intimates some important themes, while transcribing the data some important features and patterns were identified, and coded into initial codes and final codes, some academicians told the same views and shared their perception as other had told earlier, this pattern helped out to make coding scheme very easy, after developing coding scheme, repeated pattern are molded into themes. Coding process is described in (Table 1).

Thematic Analysis and Discussions 
For data analysis thematic analysis technique was used, TA is a process of identifying and analyzing patterns within text. Thematic inductive technique known as "bottom up" approach is applied to identify important views and perception within collected text or set of text, and what is in data (Braun \& Clark, 2006), as to get a sense of predominant and important themes in data (Blacker, 2009). Initially, collected data were transcribed into readable form to familiarize with data, while in second phase, important views and ideas in text are identified and assigned initial codes (see table 1) to important segments of data from collected text as data driven code scheme, in third phase, many codes are in hand that are extracted from data, now these codes are sorted into potential themes (see table 1) to find out relationship between codes and themes, in fourth phase collated themes are reviewed showing coherent patterns and fit into final theme related to data set as all respondents of study reached on same point where no more information was required, this situation is known as data saturation. In final phase final themes are named, see (table 1).

Table 1.

Questions, Initial Codes and Final Codes of Semi Structured Interviews.

\begin{tabular}{|c|c|c|}
\hline Question/Domain & Final codes and Initial codes & Final Themes \\
\hline $\begin{array}{l}\text { How Busiest schedule } \\
\text { is stressful? }\end{array}$ & $\begin{array}{l}\text { HBSS- Busiest Schedule } \\
\text { HBSS- Lack Of Time Management } \\
\text { HBSS- Training } \\
\text { HBSS- Disappointment }\end{array}$ & Time Flexibility \\
\hline $\begin{array}{l}\text { How financial } \\
\text { instability can predict } \\
\text { life threatening. }\end{array}$ & $\begin{array}{l}\text { HFIPLT- Needs } \\
\text { HFIPLT- Available Resources } \\
\text { HFIPLT- Financial Constraints }\end{array}$ & Financial Stress \\
\hline $\begin{array}{l}\text { How quality of work } \\
\text { and available facilities } \\
\text { create work pressure }\end{array}$ & $\begin{array}{l}\text { QWFWP- Resources } \\
\text { QWFWP- Proper Utilization } \\
\text { QWFWP- Educational Output } \\
\text { QWFWP- Changing Demand }\end{array}$ & $\begin{array}{l}\text { Quality Pressure and Available } \\
\text { Facilities }\end{array}$ \\
\hline $\begin{array}{l}\text { Lack of Motivation } \\
\text { and low morale }\end{array}$ & $\begin{array}{l}\text { LMLM- Low encouragement } \\
\text { LMLM- Appreciation }\end{array}$ & Lack of Motivation and Low Morale \\
\hline $\begin{array}{l}\text { Why freedom of work } \\
\text { is beneficial to reduce } \\
\text { overburden of work }\end{array}$ & $\begin{array}{l}\text { FWBROW- Freedom Of Work } \\
\text { FWBROW- More Burden Of Work } \\
\text { FWBROW-Employee Engagement } \\
\text { FWBROW- Job Satisfaction }\end{array}$ & Autonomy of Work Overloaded \\
\hline $\begin{array}{l}\text { How organizational } \\
\text { structure affect } \\
\text { working performance }\end{array}$ & $\begin{array}{l}\text { OSAWP- Particular Obligations } \\
\text { OSAWP- Organizational Structure } \\
\text { OSAWP- Smooth Functioning } \\
\text { OSAWP-CentralizedDecision } \\
\text { Making }\end{array}$ & Horizontal Structure \\
\hline
\end{tabular}

\section{Them 1: Time Flexibility}

\section{Question: How Busiest schedule is stressful?}

Busiest schedule may disappoint academia due to heavy overload need to be discussed. Get up early in the morning and go to the bed late at night, taking lectures, writing research paper, attending conferences and meetings etc. and administrative obligations are stressful for academia heads. Professional management training needed for limiting the arrangements of daily tasks to be performed at level of teacher and heads.
One of the academia (teacher) shared his experience as:

"We keep busy ourselves into different activities at universities, it take us into stress due to lack of time management. HEC requires more productive work from teachers, so we have to prepare ourselves for lectures, research supervision and other assigned tasks from academia heads. Sufficient credit hour must be assigned to academia, they must assign according to their interest and background knowledge domain".

"Another fact revolves around us that we have to concentrate more on writing research paper 


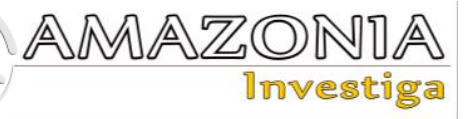

helpful for promotion. HEC shed light strict criteria for publishing research paper in HEC recognized journals. This is time consuming activity based on research, student and supervisor relationship is necessary, some time student feels reluctant to contact to teacher even final thesis or project submission date is gone to an end".

Theme 2: Financial Stress

\section{Question: How financial instability can predict life threatening.}

Everyone expect a good financial and reasonable income in his life. An individual who bears numerous problems and needs, want to use the available resources to earn more income to complete and get rid of stressful life due to financial constraints. Many of faculty members fell into these constraints. These constraints stick them into internal and external problems related to physical and psychological in nature, beside financial mode of pressure make space for its survival in human mind, that is dangerous and create problems in entire life.

Participants perceived financial stress as:

"We have spent our financial resources for getting education, many of us belong to poor and working families, our adjustment into academic environment is challengeable for us, and poorly constructed behavior controls our attitude toward others. Our relationship with peers and families are weak, lead frustration and severe health problems. These health problems devastating at individual level, mostly caused by stress and low working performance, sometime we feel out of mind due to other work obligations".

\section{Theme 3: Quality Pressure and available facilities}

Question: How quality of work and available facilities create work pressure?

Quality of HEIs is challenging due to available facilities at institutional level. Academic institutions use available resources to meet the educational output. These resources are available facilities, human resources and curriculum. Universities have two major sources of income; first one of in the form of fee collected from students, and second is of released fund from government. The proper utilization of these resources can take part its role for quality measures. Available facilities at universities like library, computer labs, furniture, IT related facilities are necessary for quality education. Some facilitates are replaceable with new facilities meeting the changing demand of quality education. The quality of these facilities is also manageable at procurement level; most of facilities that are used and near to be replaced by new one is time consuming. Responsible management may procure new facilities for replacing old one, that have been used and need to be replaced, i.e. furniture, computers, building infrastructure need to be revived for quality work.

One of faculty member (teacher) told that:

"Due to prevailing situation, online assessment and examination is challenging for teachers and student. Most of students live far away from urban areas, where intent facilities are not available, they miss their online lectures. Many of teachers are also facing while delivering online lectures, at online program, university demands the attendance of students for attending lectures, but this is not possible for teachers because the students and teachers are not physically present. Most of the students do not bother themselves to attend lectures due to connectivity issues. At assessment and examination level they face various problems, so proper guidelines and training of teachers regarding conducting online exams must be provided."

\section{Theme 4: Lack of Motivation and low morale}

\section{Question: How motivation is important to improve working performance.}

Lack of motivation and low morale highlights low working performance. While academia heads are responsible for appreciating the work of academia to boost up for equipping more energy towards achieving academic goals.

One of academia (teacher) shared his experience as:

"Low encouragement and negative feeling toward work of academia discourage teachers. The way to lose his morale and confidence directly link with working performance. Teacher is too busy in teaching, supervision and research activity, demand more encouragement from senior faculty member and head of the department".

One of Academia head said that:

"Definitely, motivation can lead more positive way of thinking, put extra energy to teacher for improving work, opposite to it stressful condition 
is not suitable for teacher who is backbone of academic institution"

\section{Theme 5: Autonomy of work overloaded}

\section{Question: Why freedom of work is beneficial to reduce overburden of work?}

Every organization entails better performance expecting from it staff. But performance may affect from work overload and relationship with colleagues. Job satisfaction relies upon employee engagement with plan to participate in different activities like seminars, conferences, meeting etc.

One of the academia shared his experience as:

"An action of staff is related with job obligation and experience bears a teacher at universities. Teachers are freer to talk about these actions with others, who are also expecting a good relationship with them to perform define goals. Long lasting relationship develop and help in with regard to any matter concerning for reducing stress level. Even the phenomena autonomy of work overload varies from person to person, sometime the work burden exceeds the personal abilities and expectations liable for job related stress can harm working performance".

Another respondent (teacher) added that:

"Everlasting relationship with others does not matter than consistency in performing different tasks in particular situation. Assigned duties are demanding struggle form academia who is more engaged with teaching, supervision, attending meeting and seminars, writing research paper, enhancing qualification, taking assessment and examination, paper setting and taking notes for students. These all obligations lead to stress and working pressure is higher than ever demanding by academia, solemnly it continues various physical and psychological health related issues. These issues must be resolved on top priority, besides these learning atmosphere and learning environment for students cannot be imparted".

\section{Theme 6: Horizontal structure}

\section{Question: How organizational structure affect working performance?}

Universities follow a distinguished model as compared to other learning institutions. Management related tasks demand some particular obligations that are affected by organizational structure. Formal obligations are practiced through organizational structure it's responsible for smooth functioning of centralized decision making. Overall functioning depends or available structure. Organizational structure is responsible about all the activities going to perform, it encourages for efficient teamwork and $\mathrm{r}$ goal attainment. Appropriate guidance is needed to achieve corporate goals. These goals are directly related with government policies, and decision making as beaureocratic model may be prolonged to impart policies. Management tasks are planning, organizing, directing, implementing and reporting. Initially take a plan set for goals to academicians, and help in providing resources for achieving these goals. Management also plan for accomplishing these plans through monitoring and evaluation. Sometime these tasks take more time and demanding more flexibility indeed for its completion.

One of head of academia told that:

"Universities have many faculties and departments that require an organized way of achieving setting for particular purposes. Academic and non academic purposes are not the same, as teaching and research demand more comprehensive informative system based on specification in recovery field. Sometime, head of the departments assign course to teacher that is out of his or her specialized domain and interest, lead to chaos. On the way teachers are reluctant to fully participate in delivering lectures and other research activities".

Centralized system of power work in particular department following the instructions of senior management. Head of department is responsible for all activities are doing within department like seminars, conferences, research activities, assign courses to teachers, conducting meetings regarding research, apart from this senior management controls and influence the decisions. Sometime, head of department face obvious behavior form department concerns those are giving non compliance of norms and official orders.

\section{Discussion}

Many studies in past have been conducted on affects of stress on student performance. Academia stress actually related with personal and organizational structure. All academicians have some knowledge of job stress, therefore, busy schedule of academia don't provide more clarity among stress behavior, for accomplishing defined purposes of establishing academic 


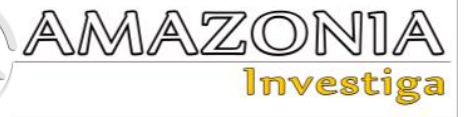

institutions, it was noted that most of academia still lack the knowledge about job stress. The finding is coincided with the work of (Gunbayi, 2014) stated that most of academic staff having no information to cope with the situation. Unfortunately, academia spends most of the time of at universities, personal life of academia still lack coordination with family, friends and relatives. Time and financial constraint may be prolonged affect on thinking and behavior of academia as asserted by Sivarajah, Achchuthan, \& Umanakenan (2014) that personal characteristics like, age, family size, education and experience is deeply rooted between financial stress and working performance. This was also endorsed by (Jamal et al., 2020) stated that multiple indicators are interlink with each other affecting job performance of academicians. Most of academia wants to earn than spending more time for research work requires encompassing global recognition as asserted world ranking of universities are underway, it depends on quality of education, especially in research related activities are imperative. Quality of education and performance come through paying reasonable salaries, retention of staff, timely promotion and equity in organization. (Khalid et. al., 2012; A'yuninnisa \& Saptato, 2015),

\section{Conclusion}

It is concluded on the basis of themes and discussion of this chapter that academia knows about the stress and have information about its severity influencing job performance. Academic institution demand more struggling behavior from academia. Academia engagement with institutional goals is obligatory to meet defined tasks and purposes of establishment of educational institutions. Personal abilities may be down and up but varies by person to person, individual working is too challengeable, academia who working in academic institutions face internal and external life threats influencing job performance. Apart from personal attributes, organizational structure impose some roles to head of the departments and teachers, responsibility relies upon to achieve goals structured by higher authorities to promote quality education to all students.

\section{Important Suggestions}

- Academia heads must assign work according to academia interest, knowledge and domain.

- There is need to investigate reasons of disappointment among academia, that is threatening for working performance.

- Work overload and autonomy need urgent concentration.

- Working management training must be conducted both for academia heads and teachers.

- Performance evaluation must be accorded with facts; in this regard political involvement must be minimized.

\section{References}

A'yuninnisa, R. N. A., \& Saptoto, R. (2015). The effects of pay satisfaction and affective commitment on turnover intention. International Journal of Research Studies in Psychology, 4(2). Badau, K. M. (2018). Administration of universities and channels of communication in Nigeria. Art Human Open Acc J, 2(5), 302-306. DOI: 10.15406/ahoaj.2018.02.00073

Blacker, R. (2009). A thematic analysis of psychodynamically-oriented supervision of observations in an acute inpatient ward. Published thesis. University of Leicester.

Braun, V. \& Clarke, V. (2006). Using thematic analysis in psychology. Qualitative research in psychology, 3(2), pp. 77-101

Etikan, I., Musa, S.A., \& Alkassim, R. S. (2016). Comparison of Convenience Sampling and Purposive Sampling. American Journal of Theoretical and Applied Statistics, 5(1), 1-4. https://doi.org/10.11648/j.ajtas.20160501.11

Fan, J. \& Smith, A. P. (2017). The Impact of Workload and Fatigue on Performance. In. Longo, L. \& Leva, M. C (Eds.), first international symposium, h-workload, Springer, Cham.

Farooq, M. B., and Villiers, C. (2017). Telephonic qualitative research interviews, when to consider them and how to do them. Meditarian Accountability Research, 25(2), 291-316.

Gashi, M. (2014). The influence of work overload and autonomy on job satisfaction, organizational commitment and turnover intent: the case of Kosovo. Published Thesis. Retrieved from: http://arno.uvt.nl/show.cgi?fid=136021 Gellatly, Ian R. \& Gregory, I. P. (2001). Personality, Autonomy and Contextual Performance for Managers. Human Performance, 43(3), 231-245

Ghabban, F., Selamat, A., Ibrahim, R., Krejcar, O., Maresova, P., \& Herrera-Viedma, E. (2019). The Influence of Personal and Organizational Factors on Researchers' Attitudes towards Sustainable Research Productivity in Saudi Universities. Sustainability, 11(17), 4804. 
MDPI AG. Retrieved from http://dx.doi.org/10.3390/su11174804

Greenberg, J and Baron, R.A. (2007). Behavior in organizations: understanding and meaningthe human side of work, Prentice Hall.

Gunbayi, A. D. (2014). Job stressors and their effects on academic staff: a case study. International Journal on New Trends in Education and Their Implications, 5(4), 58-73.

Hackman, J. and Oldham, G. (1976). Motivation through the design of work: A test of a theory. Organizational Behavior and Human Performance, 16(2), 250-279.

Hellriegel, D., Slocum, J.W (2004). Organizational Behavior, Thomson Learning pub. Ed. 10th, 168.

Holstein, J.A., and Gubrium J.F. (2003). Inside interviewing: New lenses, new concerns. In: Holstein JA, Gubrium JF, editors. Inside interviewing: New lenses, new concerns. Thousand Oaks: Sage, pp. 3-30

Irvine A. (2011) Duration, dominance and depth in telephone and face-to-face interviews: A comparative exploration. International Journal of Qualitative Methods, 10(3), 202-220

Ivancevich, J. M., and Matteson, M. T. (2002).Organizational and behavioural Management. McGraw-Hill Publication.

Jamal, A., Chaudhry, A., Mahmood, B., Siddique, S. \& Ashraf, M.F. (2020). Effects of job stress on performance of accademicians working in public sector universities of Punjab. PalArch's Journal of Archaeology of Egypt / Egyptology, 17(4), 1313-1328. Retrieved from

https://archives.palarch.nl/index.php/jae/article/ view/595

Jamal, M. (2005). Burnout among Canadian and Chinese employees: A cross-cultural study. European Management Review, 2, 224-230

Khalid, S., Irshad, M. Z., \& Mahmood, B. (2012). Job satisfaction among academic staff: A comparative analysis between public and private sector universities of Punjab, Pakistan. International journal of Business and Management, 7 (1), 126

Khan, A., Md Yosoff, R. B., and Azam, K. (2014). Factors of job stress among university teachers in Pakistan: A conceptual view. Journal of Management Info, 2(1), 62-67.

Masum, A. K., Azad, M. A., and Beh, L. S. (2015). Determinants of academics' job satisfaction: empirical evidence from private universities in Bangladesh. PloS one, 10(2), e0117834.

https://doi.org/10.1371/journal.pone.0117834

Morrison, D., Cordery. J., Antonia, G., and Roy, P. (2005). Job design, opportunities for skill utilization and instrinsic job satisfaction. European Journal of Work and Organizational Psychology, 14(1) 59-79.

Osipow, S. H., \& Spokane, A. R. (1983). The occupational environmental scales, the personal strain questionnaire and the personal resources questionnaire. Columbus, $\mathrm{OH}$ : Marathon Consulting and Press.

Prerna and Agrawal, K. (2018). Job Stress And Its Impact On Job Performance: A Case Study On Academic Staff At Amity University. International journal for research in engineering application \& management (IJREAM), 4(6), 261-266. DOI : 10.18231/2454-9150.2018.0726

Sivarajah, K., Achchuthan, S., and Umanakenan, R. (2014). Financial Stress and Personal Characteristics of the School Teachers: Evidence from Sri Lanka. Public Policy and Administration Research, 3(4), 40-49.

Stephens, N. (2007). Collecting Data from Elites and Ultra Elites: Telephone and Face-to-Face Interviews with Macroeconomists. Qualitative research, 7(2), 203-216.

Toohey. (1995). The communicational model of Stress in employees. Organizational Behavior, 9(3), 203-207.

World Bank. (2007). World Bank Report on Pakistan: Country Summary of Higher Education. Retrieved from http://siteresources.worldbank.org/education/res ources/278200-1121703274255/14392641193249163062/pakistan-country-summary.pdf Zafar, Q., Ali, A., Hameed, T., Ilyas, T., and Younas, H. (2015), The Influence of Job Stress onEmployees Performance in Pakistan. American Journal of Social Science Research, 1(4), 221-225. 